\title{
DISTRIBUTED PARTICIPATION AND RESPONSIBILITY - IN COMPETENCE APPROACH REALIZATION IN EDUCATION
}

\author{
Kristīne Niedre - Lathere \\ University of Liepaja MBA, Latvia \\ Alīda Samuseviča \\ University of Liepaja FPSW, Latvia
}

\begin{abstract}
Humankind is facing unprecedented revolutions, all our old stories are crumbling, and no new story has so far emerged to replace them. How can we prepare ourselves and our children for a world of such unprecedented transformations and radical uncertainties. What and how should we teach a child that will help them survive and flourish in the $22^{\text {nd }}$ century? What kind of skills will they need in order to get a job, understand what is happening around them and navigate the maze of life?

In the publication topicality of all participants', involved in the educational process, distributed partnership and responsibility has been raised and characterized in the context of the education reform implementation - in transition to the education based on competences. The need for teachers' professional activity in efficient provision of cooperation with parents and the society is especially emphasized, as well as topicality for new productive cooperation models, which provide an opportunity to increase the new generation and society's demand qualitatively for a new education content, knowledge, values and competences that are able to guarantee a purposeful and sustainable development both on the individual and Latvian national level.
\end{abstract}

Keywords: responsibility, education, competence approach, participation, cooperation, teacher, parents.

\section{Introduction}

In Latvia, upbringing of the new generation is one of the most topical issues, as in the national growth model the human is the main driving force, their knowledge, wisdom, skills and the desire to cultivate and apply them actively. Since the early 90 s of the $20^{\text {th }}$ century in the society of Latvia essential changes have happened both in the political, economic, social and cultural areas that have also affected youth and children's value orientation. A lot of negative features have emerged alongside the acquisition and reinforcement of the values characteristic to a democratic society, which is related to various addictions, 
intolerance, violence and permissiveness amongst children and youth (Hargreaves, Boyle, Harris, 2014). The society's demand for new educational standards and pedagogical work strategies, which help pupils see and solve problems in compliance with the context of social reality, has been justified.

The education reform in Latvia is a topicality which announces the need for new skills, knowledge, values, habits in the school learning content, offering the $21^{\text {st }}$ century competence models in order to transform education goals and they would comply more adequately with the changes in the society's development and economics. The term competence is in the centre of educational changes. Competence is the individual's ability to apply knowledge, skills in a complex way and manifest attitudes, solving problems in the changeable real-life situations, which complies with the definition of OECD "Education 2030." Competence is complex, its development is related to transition formation for action in a new situation, new contexts, they cannot be reduced to a separate skill or an isolated set of knowledge. 'In order the pupils' learning outcome would be a competence, the teacher's skills to manage appropriate learning, analyse and reflect, cooperate become topical." (Learning for proficiency, 2018, 13). As the competence develops in diverse contexts of the pupil's personality formation, then its purposeful development cannot be imagined apart from the border extension of the educational environment and new educational agents' involvement. Parents, family and the society have to become as significant elements of the educational process, who are not only informed about the changes in education, but also give their contribution in provision and improvement of the educational field's quality, taking civic participation and being responsible for the new generation's purposeful growth.

Assessment of pedagogical reality within the framework of the authors' professional experience and research of the current theoretical experience enables us to identify one of the contradictions in the education reform implementation process, which is topical in the current situation and an unaware issue in research: insufficient actualization of distributed participation and responsibility in the strategical development for the education reform.

The set of changes in education, also including in teacher education and further education after Latvia's independence restoration has been little studied, there are few studies on the fundamental changes in teacher education (Blūma, 2016). Issues on a purposeful and qualitative parents' engagement and motivation of their distributed responsibility, on the teacher's professional contribution and competence in a productive cooperation provision have been referred theoretically and practically insufficiently. 
Distributed Participation and Responsibility - in Competence Approach Realization in Education

Goal of the article: raise the issue of the significance of the efficiency of the teacher's activity in parents and society's distributed participation and responsibility provision in education reform realization, setting research issues for innovative cooperation model development for the research of competence approach realization in the modern school.

Methodology of the research: development of the article is based on the analysis of the normative base cognitions and theoretical literature studies on the education reform development and implementation.

\section{Topicalities and Perspective of Significance}

According to the requirements of the educational field's normative acts, parents and the family have to take the main care of the child and their education and upbringing. However, the educational establishment's task is to provide a qualitative educational process which comprises in itself learning and upbringing activity, due to which pupils acquire knowledge, skills and abilities and form attitude towards themselves, other people, work, cultural values, society and state. Thus, children's upbringing becomes a purposeful, long-lasting and successive process, which is implemented by the family, cooperating with the educational establishment and governmental and public support. All people involved in the upbringing work, including pupils, parents, pedagogues, responsible institutions and organizations and the society in general, have to be responsible for the knowledge, understanding and adherence to their responsibilities and rights.

As a result of upbringing the value-education is implemented, which in the pedagogy scientists' (Belickis, 2000; Špona, 2001; Līdaka, 2007; Oliņa, 2018; Namsone, 2018 etc.) explanation is refinement of the person's principal values spirituality, moral, culture, intelligence and physical posture; cultivation of the person's self-awareness, awareness of the inherent value, self-reflection, linguistic ability and creativity; development of tolerance, reconciliation abilities, sympathy etc. human abilities; introduction , motivation and preparation for a successful professional career. Upbringing work is directed to the youth and child's holistic awareness of values and formation of an assessing attitude and responsibility for their action.

Our future partly depends on our values. The society's values determine action and way of thinking cogitated by people, which is necessary in order to change the world. Therefore, the education of the $21^{\text {st }}$ century has a special topicality in the society's development. Our education systems have to 
concentrate on generally positive goals, providing personal competences, knowledge and wisdom to all pupils (Fadels, Bialika \& Trilings, 2017).

Acquisition of the universal human values and different social or life-skills is implemented during the whole educational process according to the national education and subject standards. Learning and upbringing activity is implemented during classes and out-of-school activities in an educational establishment, which is a mutually related, inseparable and united process. In the educational process the pupils' achievements are evaluated: pupils' knowledge, skills and abilities. Nevertheless, uncertainties emerge when evaluating pupils' attitudes (measuring). Also, pupil's behaviour is not evaluated, since there is not one unambiguous society or teachers' opinion on whether behaviour in general can be assessed, how impartially and according to what criteria it can be carried out.

Inquiring and studying terminology in English and Latvian, the explanation for the concept distributed responsibility is mentioned as something that is responsible (for something) together with somebody. In its turn, proceeding with the cognitive process, it can be realized that novelty in pedagogy is reflected with this term. This is the fact that mostly promotes a purposeful interest in a more profound analysis of matters and processes, for neither in school management nor pedagogical process the key of successful outcomes and achievements can be imagined without the presence of distributed responsibility and individual contribution, as well as without a highly professional teachers' competence.

Lots of new and significant ideas experience failures in a long-term perspective due to different reasons, very often it is lack of consequence and competence.

Getting familiar with the emphasized aspects in the Finnish model of education, one can notice the comparison of several essential educational transformation factors.

Table1 Basic virtues and capital sins in transferring innovations (Makela, 2013)

\begin{tabular}{|l|l|}
\hline \multicolumn{1}{|c|}{ Basic virtues } & \multicolumn{1}{c|}{ Capital sins } \\
\hline $\begin{array}{l}\text { Establishing clear goals and } \\
\text { determining the needs }\end{array}$ & $\begin{array}{l}\text { The innovations that are being transferreddo no } \\
\text { meet the needs for development of the } \\
\text { organisation or its employees }\end{array}$ \\
\hline Good planning & Poor and/or inadequate planning \\
\hline $\begin{array}{l}\text { Commitment and committing of key } \\
\text { actors }\end{array}$ & $\begin{array}{l}\text { Insufficient amount of time and resources sent on } \\
\text { committing the actors, and the actors are unable to } \\
\text { argue the importance of the new practices in a } \\
\text { sufficiently convincing way }\end{array}$ \\
\hline
\end{tabular}


Distributed Participation and Responsibility - in Competence Approach Realization in Education

\begin{tabular}{|l|l|}
\hline $\begin{array}{l}\text { Continous evaluation and } \\
\text { preparedness to take corrective action, } \\
\text { if necessary }\end{array}$ & $\begin{array}{l}\text { There is no evalution plan prepared for the } \\
\text { transfer process }\end{array}$ \\
\hline Successful panting and dissemination & $\begin{array}{l}\text { Information and communication is inadequate, } \\
\text { actors assume the practices will take root and } \\
\text { spread by themselves }\end{array}$ \\
\hline $\begin{array}{l}\text { Long-term collaborative relationships } \\
\text { and mutual trust }\end{array}$ & $\begin{array}{l}\text { Searching for best practices here and there without } \\
\text { local help, short-term collaborative relationships }\end{array}$ \\
\hline $\begin{array}{l}\text { Deep understanding of the practices } \\
\text { that are being transferred }\end{array}$ & $\begin{array}{l}\text { Those that carry out the project are not familiar } \\
\text { enough with the best practices and all their details } \\
\text { to able to transfer these practices, so that new } \\
\text { actors can adopt them }\end{array}$ \\
\hline $\begin{array}{l}\text { Openness and the ability to identify } \\
\text { opportunities }\end{array}$ & Focusing on obstacles and problems \\
\hline $\begin{array}{l}\text { Willingness to also listen to alternate } \\
\text { ideas and the opinions of those who } \\
\text { oppose the change }\end{array}$ & Blindness to paths that divert from one's own plan \\
\hline Perseverance & Subbornness \\
\hline
\end{tabular}

"Nowadays, the world is characterized by globalization, development of information technologies and diversity of values, thus the human activity becomes broader and less predictable in the most varied areas. If we wish to live in a developed society in the future, then today's children have to learn to live in the world, which changes constantly, and be ready to create in the future an economic, political, social and cultural environment that has not been experienced before. Now pupils of Latvia are good at tasks which require to remember or act in familiar situation. However, they lack abilities and experience to probe and process multiform data, work in a team, offer solutions to non-standard situations, form correlations between the theoretically acquired and really experienced in life, analyse the accomplished and set goals for the next work. Pupils lack skills to implement their intentions in new conditions." (Education Concept "School 2030)

Due to cooperation and distributed responsibility it is possible to improve the competency of all components involved in the upbringing and educational processes, raising awareness of the value orientation changes in the society, to achieve purposefully and systematically a qualitative performance in both socialization and qualitative educational process organization and management. 


\section{Practical Activities and Experience Prospects}

Education Authority of Liepaja City administers and provides support to 21 preschool educational establishments, as well as 3 privately owned institutions, 15 municipal comprehensive schools and 2 private schools. In Liepaja 3,425 learners are educated on the preschool level, 8,505 pupils attend schools. Competent and motivated teachers work with this impressive number of learners, where 493 teachers work in preschools and 844 teachers on the level of comprehensive education. Teachers' work is assessed annually, and different motivating mechanisms are found in order to encourage teachers to find innovative approaches in education content implementation. In Liepaja the teachers' competition "Darbs Dara Darîtāju" / "Work Makes the Doer"/ has already been implemented for 3 years. Its goal is to be aware and promote innovations in the educational field in Liepaja and promote implementation of new ideas that provide learners with a better knowledge and skill acquisition in lessons and out-of-school work (creativity, critical thinking, communication, cooperation etc.) (Education Concept of Liepaja City 2015-2020).

Education Authority of Liepaja City has set the child/pupil as an individuality for the base of its activity, and all activities have to be directed so that they would promote pupils' achievements involving all responsible parties. The framework of the learning content consists of virtues, through skills, understanding and basic skills in learning areas. The pupil's learning outcome is proficiency, if the teacher integrates the dimensions of the content in the learning process, paying attention to both the pupil's ability to apply knowledge and skills consensually in diverse situations, and through skill development and habit reinforcement, which are based on values.

Values make an important part of proficiency. That is the base for habits, which purposefully developed, strengthen into virtues, or in other words, is already acquired and for oneself accepted values. The dimension of values in the learning content is based on the values stated in the Constitution of the Republic of Latvia, General Human Rights Declaration and European Human Rights Convention.

The task of the school is to create a comprehensive understanding in pupils on such values as life, human dignity, freedom, marriage, work, nature, culture, the Latvian language and Latvia State, creating an assessing attitude and responsibility for oneself and one's action. The vision about the pupil, who is the base of the learning content, includes important habits due to whose systematic reinforcement the following most essential virtues are created: 
Distributed Participation and Responsibility - in Competence Approach Realization in Education

- $\quad$ responsibility - the will and ability to forecast consequences of own choice and action, and act, respecting the other person's dignity and freedom;

- $\quad$ diligence - industry, assiduity, accuracy and the will to perform any work as purposefully, qualitatively and efficiently as possible;

- $\quad$ courage - decisiveness, overcoming fears, character rigor, assessment of the situation and respectful action, initiative, strive for the fair and good;

- $\quad$ honesty - reliability, genuineness, conformity of work and words;

- $\quad$ wisdom - ability to apply knowledge to promote the good in own and social life;

- $\quad$ kindness - favour, responsiveness to others, politeness;

- compassion - developed empathy, desire to feel the other person's emotional experience and an active supporter;

- moderation - balance between action and opinions, ability to separate reasonable desires from unreasonable ones and refuse from the useless, abstention from everything that encumbers personal development;

- composure - control and management of behavioural and emotional expressions, respecting own and other people's freedom, also respecting oneself and others;

- $\quad$ solidarity - mutual support and coherence of action, care of own, other people's and common benefit, a democratic dialogue with others;

- justice - honest decision-making, observation of human rights and other sensible interest and moral norms;

- $\quad$ tolerance - patience, desire to understand the different (e.g. the person's outer appearance, health conditions, behaviour, opinion, faith, customs). Nobody can teach or instil directly either values or morals, thus the teachers' task and responsibility is to strengthen habits. This is reflected very successfully in the project Skola 2030 by National Centre for Education (National Centre for education www.domaundari)

People acquire values and their expression during their whole life, also outside the walls of educational establishments. According to the observations of the pedagogical practice it can be confirmed that pupils see the values important for them in the daily communication and interaction both in the family, at school, among friends and a wider community circle.

Through skills comprise significant cognitive, affective and social aspects of the pupil's action, which relate to all directions of human action. Through skills 
facilitate acquisition of knowledge in different contexts and with various thinking and self-managed learning techniques, thus strengthening attraction of new knowledge with the personal experience. In its turn, application of through skills in different learning areas strengthen pupils' abilities to apply them independently and in the most diverse situations, including the complex and unpredictable ones. The pupil has acquired through skills - introspection and self-management, thinking and creativity, cooperation and participation, digital skill.

Cooperation and participation skills form and develop for every individual, first of all, in the family environment: during the upbringing process, acquisition of values and cultural traditions, world revelation and socialization. When cooperating, the pupil establishes sustainable habits in their communication and interaction with peers, orientating towards the common, jointly reachable result; acquire skills to TALK, GET ON WELL and COOPERATE in heterogenous groups, reaching commonality of opinions in controversial issues and agreeing upon consensual action towards common, jointly achievable goals. The pupil is not only able, but also willing to cooperate with peers, and sustainable habits to solve interpersonal communication problems form in them, searching for and finding opportunities to notice and approximate the different needs, interests and opinions. The pupil, while participating, thinks and acts as a responsible citizen of the society; considers multiform interests, assesses and cooperates with others and solve together controversial and complex problems, which affect the present, future and sustainable development without threatening the future generations and their needs; is able to put up with uncertainty and ambiguous situations.

The roles of education levels are important in the educational process planning and implementation. The role of preschool is to lay the foundations for children's through skills, which could be later applied in substantial contexts. In basic school children have to acquire basic skills in diverse areas of human activity, through skills, habits so that they could proceed with studies in their whole life, so that pupils understand what they are going to do next in their education. The role of secondary school is an individual probing according to the goals, first of all, probing and generalizing the foundations once again, but now on a higher level (Class 10/11) - then learning more profoundly, in a narrower field (Class11/12). It is not possible to implement all of the previously mentioned new generation's educational goals without a conscious and purposeful cooperation of the family and school in the mutual responsibility and distributed responsibility topicalization in the modern pedagogical process, orientating towards the learners' learning proficiency provision in the educational environment. 
Distributed Participation and Responsibility - in Competence Approach Realization in Education

\section{Conclusions}

The analysis of theoretical literature and observations in practice confirm that in Latvia cooperation dimensions in responsibility and distributed responsibility promotion in education on a scientific level have not been studied sufficiently. The potential of Latvia's growth is greatly related to the possibilities of human capital development. Education is one of the most essential resources for growth. The documents planning Latvia's growth - Sustainable Development Strategy of Latvia 2030 (SDSL, 2030) and National Development Plan 2014-2020 (NDP, 2014-2020) justify the need for an innovative educational paradigm: education that would be able to offer a modern on practice based cooperation model in the education system which would enable us to improve efficiently the skills of cooperation and distributed responsibility in communication and cognitive processes, for the goal of education: pupils - are purposeful creators of their personal and professional future, who have acquired the basic skills required in the knowledge society in important human activity's areas; they learn with an interest, responsibly and skilfully; participate in social life thoughtfully, cooperate, are patriots of Latvia; create innovatively and productively and have obtained a healthy lifestyle habits.

Collating the previously topicalized information and its topicality in the education reform development and implementation context, several research issues can be set:

1) Is distributed participation and responsibility a novelty in the $21^{\text {st }}$ cent. educational space, or an integral need of the education process, so that any component of the process would be ready for a new education standard - implementation of education content based on proficiency?

2) What do we understand and comprehend with the term cooperation, distributed responsibility/shared co-responsibility, involvement (distributed leadership- engagement) and teachers' learning through cooperation (teacher collaborative learning)?

3) What collaboration models are topical for teachers and administrations of educational establishments in order to motivate parents and provide promotion of their maximally efficient participation and distributed responsibility in the educational environment?

4) What are the main benefits and challenges of the teacher collaborative learning in the professional growth context, becoming real agents of changes. 
Further a purposeful and systemic implementation of action research has been envisaged in order to discover and topicalize in a theoretical and empirical study the necessary information for solutions to the research issues, thus developing pedagogical reality in cooperation and distributed responsibility promotion during the course of educational processes.

\section{References}

Bel̦ickis, I. (2000). Vērtīborientētā mācību stunda. Rīga: RaKa.

Blūma, D. (2016). Skolotāju izglītība Latvijā paradigmu maiņas kontekstā (1991 - 2000). Monogrāfiju sērija. Izglītības pētniecība Latvijā Nr.9. Rīga: LU PPMF Izglìtības pētniecības institūts.

Boyle, A., Hargreaves, A., \& Harris, A. (2014). Upliftng Leadership. USA.

Fadels, Č., Bialika, M. \& Trilings, B. (2017). Četru dimensiju izglītība. Lielvārde: Izglītības uzṇēmums „Lielvārds”.

Līdaka, A. (2007). Ieteikumi vērtībizglītības realizācijai I. Liepāja: LiePA.

Makela, M. (2013). Reaching the Peak. Finland: European Social Fund.

Mācīšanās lietpratībai. (2018). Kolektīva monogrāfija. Zin. red. D.Namsone. Rīga: LU Akadēmiskais apgāds.

Špona, A. (2001). Audzināšanas teorija un prakse. Rīga: RaKa.

Izglìtības koncepcija "Skola2030" . Pieejams htttp://www.domaundari

Valsts Izglītības un satura centra projekta „Skola 2030” koncepcija. Pieejams htttp://www.skola2030.lv

VISC (2016). Ceḷā uz kompetenču pieeju mācībām. Pieejams www.skola2030.lv 